\title{
Working
}

Paper 


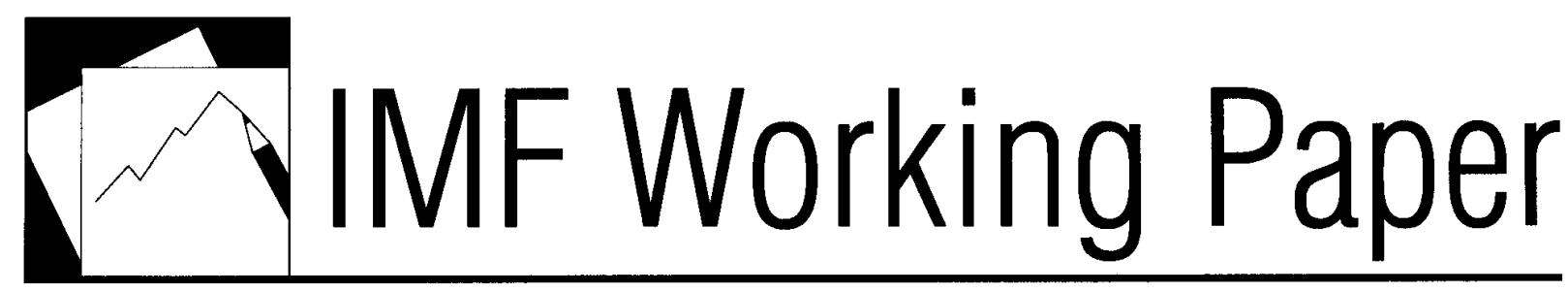

\section{Government Bonds and Their Investors: What Are the Facts and Do They Matter?}

Jochen R. Andritzky 
This page intentionally left blank

CInternational Monetary Fund. Not for Redistribution 


\title{
IMF Working Paper
}

Fiscal Affairs Department

\section{Government Bonds and Their Investors: What Are the Facts and Do They Matter?' Prepared by Jochen R. Andritzky \\ Authorized for distribution by Martine Guerguil}

June 2012

\section{This Working Paper should not be reported as representing the views of the IMF.} The views expressed in this Working Paper are those of the author(s) and do not necessarily represent those of the IMF or IMF policy. Working Papers describe research in progress by the author(s) and are published to elicit comments and to further debate.

\begin{abstract}
This paper introduces a new dataset on the composition of the investor base for government securities in the G20 advanced economies and the euro area. During the last decades, investors from abroad have increased their presence in government bond markets. The financial crisis broke this trend. Domestic financial institutions allocated a larger share of government securities in their portfolios, as Japan has done since its crisis in the 1990s. Increases in the share held by institutional investors or non-residents by 10 percentage points are associated with a reduction in yields by about 25 or 40 basis points, respectively. The data show a varied lead-lag relationship between bond yields and investor holdings. Portfolio balance estimates suggest that a change in statutory or regulatory holdings of government securities to the tune of 10 percent of the outstanding stock causes expected returns to decline by 7 to 25 basis points.
\end{abstract}

JEL Classification Numbers: G11, H63

Keywords: Public debt, government bonds, investor base, advanced market economies Author's E-Mail Address: jandritzky@imf.org

\footnotetext{
${ }^{1}$ Comments and helpful thoughts are gratefully acknowledged from Serkan Arslanalp, Max Fandl, Martine Guerguil, Manmohan Kumar, Andre Meier, Christian Schmieder, Tobias Wickens, and participants at the IMF seminar. I would also like to thank Petra Dacheva and Carsten Jung for outstanding research assistance.
} 


\section{Contents}

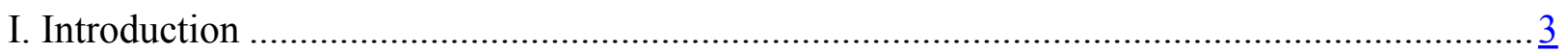

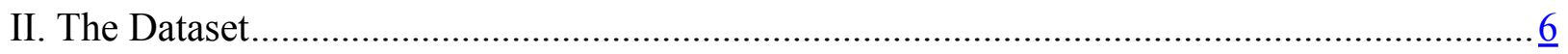

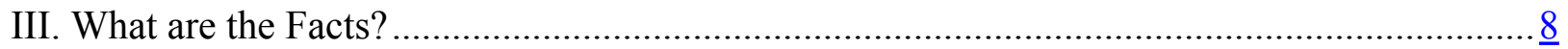

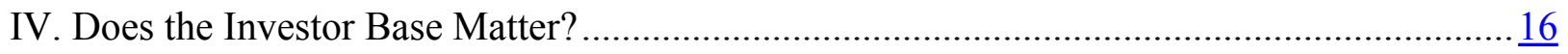

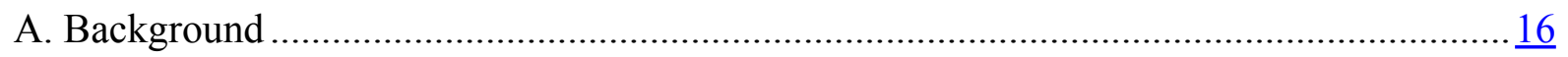

B. How Is the Investor Base Related to Yields? ............................................................

C. Do Portfolio Shifts Affect Expected Bond Returns? .........................................................

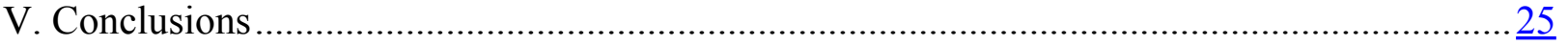

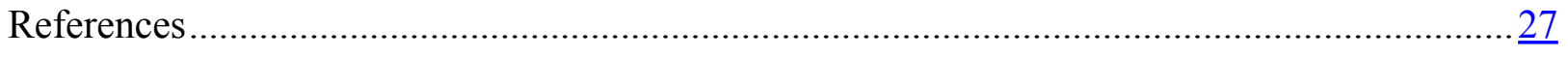




\section{INTRODUCTION}

The recent crisis has led to a change in investors' demand for government bonds amid increased issuance volumes. Prior to the crisis, a narrowing supply of new government securities was increasingly taken up by non-resident investors, often undercutting bids from domestic accounts. Since the onset of the crisis, the investor base of government securities has shifted back towards domestic holders. Central banks have become important players in the government bond market as a result of quantitative easing programs. Also, commercial banks started to hold more government bonds, partly to obtain collateral, despite a reduction in their overall balance sheet. With financial globalization stagnating and global imbalances on the back foot, the underlying drivers of higher non-resident holdings have weakened for some time.

\section{The widely observed shift in the investor base has prompted policy makers and} investors to inquire about the implications of changes in bond ownership. Policymakers have recognized the importance of knowing their investors and the role of financial interlinkages between sectors of the economy. Investors and their intermediaries have become wary of the behavior of competing types of investors. This paper attempts to address two of the myriad of questions that have arisen from the newly gained attention to the investor base:

- Which investor groups hold what exposure to government securities?

The question has been of interest, for instance, with regard to contagion risk from euro-area government bonds. More broadly, the question is of relevance in evaluating options on issuance strategies, prudential regulation, collateral policy, and mitigating bond market pressures through what has been labeled "financial repression" (Reinhart and Sbranica, 2011).

\section{- Is there a link between the investor base and bond pricing?}

Anecdotal and empirical evidence has motivated the hypothesis that non-resident demand reduces yields while inducing volatility in response to changes in fundamentals and market sentiment (Beltran et al., 2012; Peiris, 2010). In contrast, the presence of a stable domestic investor base that includes institutional investors is thought to contain yields and foster stability in bond prices and yields. Institutional investors could be induced to increase their holdings by tightening prudential regulations. These mandated purchases, comparable to statutory purchases by central banks as part of quantitative easing programs, could have a similar effect on yields (Neely, 2010; Joyce et al., 2010).

This paper addresses these questions based on a cross-country dataset of the advanced G20 countries and the euro area. ${ }^{2}$ Its objective is to test the above hypotheses in the

\footnotetext{
${ }^{2}$ Besides the aggregate euro area, the following member countries are included: France, Germany, Greece, Ireland, Italy, Portugal, and Spain.
} 
context of a wider country sample. The country heterogeneity in the sample differentiates this paper from other contributions that are essentially case studies of one or a few comparable countries. ${ }^{3}$

\section{Existing studies provide country-specific evidence for the relationship between the} investor base and yields. In Japan, a large domestic investor base has been associated with the low and stable yields despite very high debt (Tukuoka, 2010; Fidora et al., 2006). This large domestic investor base is mostly a result of the accumulation of pension savings through deposits and investment funds, coupled with a strong home bias. In the euro area, equal regulatory treatment and the perception of homogenous credit risk has fostered investors' desire to diversify, thereby increasing the share of cross-holdings by non-residents (De Santis and Gerard, 2006). While increased cross-holdings may have contributed to the dramatic convergence of euro area yields when the euro was introduced, cross-holdings continued to increase even after and reversed only recently. In the United Kingdom, longterm yields declined following the increase in pension funds' holdings of gilts (Greenwood and Vayanos, 2009). This portfolio shift, in particular into ultra-long gilts, has been attributed to amendments of U.K. pension fund regulations with the aim of reducing the maturity mismatch between assets and pension liabilities. Mainly for the United States and the United Kingdom, large-scale asset purchases by central banks have had small yet notable effects on yields. ${ }^{4}$

\section{While case studies can plausibly explain country idiosyncrasies, a broader study design helps to establish generally applicable relationships. Although the above case studies} suggest a forceful connection between bond yields and the investor base, a broader analysis could help determine whether any change in the investor base goes along with a yield change of significant dimension. Theoretical considerations suggest that changes in the composition of the investor base are associated with changes in the level or slope of the yield curve only to the degree that investor groups hold different perceptions or risk preferences. ${ }^{5}$ This argument has been made in relation to the re-investment of accumulated reserves, which in large parts were invested into government bonds of reserve currency issuers without regard to risk considerations, causing a secular decline in yields (Warnock and Warnock, 2006). More recently, however, reserve managers started to spread their investments more broadly and apply risk management techniques similar to other investors (Borio et al., 2008;

\footnotetext{
${ }^{3}$ See, for instance, Krishnamurthy and Vissing-Jorgensen (2010) on the demand for U.S. Treasury bonds; Gagnon et al. (2010) on the supply of government bonds and quantitative easing in the U.S.; Beltran et al. (2012) on foreign demand for U.S. Treasury bonds; or Greenwood and Vayanos (2009) on U. K. pension fund regulations. Also, the paper complements the literature that focuses on external debt, which largely corresponds to non-resident debt holdings. See Peters (2002) for an overview of the empirical literature using external debt as determinant of emerging market debt crises.

${ }^{4}$ Empirical investigations indicate that statutory purchases of up to 15 percent of the outstanding debt stock have a rather moderate impact of 20 to 100 basis points in the short run while long-run effects are usually lower. See D'Amico and King (2010), Gagnon et al. (2010), Krishnamurthy and Vissing-Jorgensen (2011), Neely (2010), or Joyce et al. (2010), among others.
}

${ }^{5}$ See Section IV.A for a discussion of the theory. 
Papaioannou et al., 2006). It is therefore not very evident that certain investor types hold starkly different preferences. This paper steps away from investigating specific trends (such as reserve accumulation) or policy actions (such as quantitative easing or regulatory reforms) and poses the question of the relevance of the investor base in broader terms. On the one hand, the consequence of such an approach is that the empirical results are likely to be less strong compared to investigating specific trends or policy actions. On the other hand, any robust empirical result arising from this study design does carry important signals, which may prompt a new interpretation of existing evidence and caution against premature policy conclusions.

\section{The econometric results from this paper confirm that an increasing share of non-} resident investors is associated with lower yields. Regression analysis shows that the share of securities held by non-residents is negatively correlated with bond yields. An increase (decrease) in non-resident investors by 10 percentage points is associated with a reduction (increase) in yields of between 32 to 43 basis points, whereby the effect is stronger for euro area countries. The data also provide evidence that volatility increases in the presence of nonresident investors. However, the relationship between non-resident holdings and yields does not yet establish whether causality exists between the two. While the arrival of non-resident buyers, for whom foreign bonds may offer a diversification benefit, is often associated with a drop in yields ("push effect"), it could also be low stable yields based on sound macroeconomic fundamentals that attract foreign buyers ("pull effect"). ${ }^{6}$ Granger causality tests show a multifaceted lead-lag relationship between changes in holdings and yields. Using a VAR analysis, this paper finds no significant evidence for the push effect, while the statistical relation between non-resident investors and yields appears to originate from a pull effect in the joint sample.

\section{The paper also finds that domestic institutional investors are associated with lower yields, but public sector holdings are not. Regressions show that lower yields are} associated with domestic institutional investors, who - in contrast to banks - are not leveraged buyers and are better positioned to hold investments through a trough (IMF 2012). No significant effect is identified for holdings by the public sector (which includes central banks).

\section{Mandated bond purchases are not found to trigger a sizable decrease in yields in a} portfolio balance model. A portfolio balance approach is used to estimate the possible effect if the share of government securities in mean-variance optimized portfolios were to change. The portfolio balance model translates a change in the weight of government securities in portfolios into the change in expected returns so that ceteris paribus investors maintain an optimized portfolio. The approach is suitable to estimate the possible impact of a nonvoluntary change in portfolio weights, for instance in response to regulatory reforms, shifts in supply, or statutory purchases from accounts that do not apply portfolio optimization. Results point to a fairly muted response. A 10 percentage point decrease in the portfolio weight of

\footnotetext{
${ }^{6}$ Previous studies on foreign investment flows into emerging markets have found a strong relationship with macroeconomic and institutional factors. See Bekaert and Harvey (2003) for an overview of the literature.
} 
government securities in optimized portfolios results in a decrease of expected annual returns by 0.07 to 0.25 percent.

The remainder of this paper is structured as follows. Section II introduces the dataset. Section III illustrates the data, providing insights on sectoral exposures to government securities in the sample of 13 countries. Section IV conducts some econometric analysis to gauge whether the composition of the investor base is related to bond yields. Section V summarizes.

\section{The Dataset}

\section{The dataset attempts to break down individual country data according to a common} typology of investors. All data were collected from publicly available sources, with the exception of Canada where Statistics Canada composed data for the purpose of this study. In line with other statistics on marketable securities, data are presented on an unconsolidated basis where available. The classification of holders follows the ESA95 sectoral breakdown but uses the broader concept of the "public sector" instead of "general government". The domestic private non-financial sector is broken down into non-financial corporations and direct household holdings, both of which hold very small portions of marketable government securities directly and are therefore often omitted from the analysis. The domestic financial sector is broken down into banks (excluding the central bank where possible), insurance and pension funds, and other financial institutions. Except for a few countries, no further breakdown is available for non-resident investors.

The coverage of debt instruments and their valuation differ across national sources. The database gathers information on marketable government debt traded widely among the different investor classes. Therefore, it excludes debt marketed to certain investors (such as retail products), municipal debt, or non-marketable securities, where possible. Close substitutes to government securities, such as bonds of state-owned enterprises, are also excluded. Data availability, however, sometimes requires compromises. As Table 1 shows, many countries do not provide a breakdown by holders for marketable central government debt but instead for consolidated general government debt. Outstanding amounts may be reported at nominal or market value, although the difference between the two is small in most cases. Because of differences in the consolidation level, coverage, and valuation, the aggregate debt covered in this database does often not match official statistics on consolidated general government debt. Differences are largest for countries with large amounts of debt issued by entities other than the central government or significant amounts

\footnotetext{
${ }^{7}$ Holdings of the public sector include holdings of the all levels of the government, social security funds, and state-owned entities, such as the domestic central bank and public pension funds which are classified as financial sector in ESA95. Data on central bank holdings are available for all countries except for Korea, Greece, Ireland, and Spain. While other intragovernmental holdings are often available for other countries, social security and public pension fund holdings are readily available only for Canada and Japan. For the United States, the data are sourced from the United States Social Security Administration (www.ssa.gov).
} 
of non-marketable debt. Notwithstanding these differences, in the remainder of this paper the term "government securities" will be used when referring to the debt covered in this database.

Table 1. Data

\begin{tabular}{llllll}
\hline Country & Coverage & Instruments & Valuation & Latest data & Source \\
\hline Australia & General government & Securities & Nominal value & $2011 Q 4$ & Reserve Bank of Australia \\
Canada & General government & Securities & Market value & $2011 Q 4$ & Statistics Canada \\
France & General government & Liabilities & Nominal value & $2010 Q 4$ & ECB \\
Germany & General government & Liabilities & Nominal value & $2011 Q 3$ & Bundesbank \\
Greece & General government & Liabilities & Market value & $2011 Q 3$ & Bank of Greece \\
Ireland & Central government & Bonds & Nominal value & $2011 Q 3$ & Central Bank of Ireland \\
Italy & General government & Securities & Market value & $2011 Q 3$ & Banca d'Italia \\
Japan & Central government & Bonds & Nominal value & $2011 Q 1$ & Bank of Japan \\
Korea & Central government & Bonds & Nominal value & $2011 Q 3$ & Bank of Korea \\
Portugal & General government & Liabilities & Nominal value & $2010 Q 4$ & Banco de Portugal \\
Spain & Central government & Securities & Nominal value & $2011 Q 3$ & Banco de Espana \\
United Kingdom & Central government & Bonds & Market value & $2011 Q 3$ & ONS, DMO \\
United States & Central government & Securities & Nominal value & $2011 Q 3$ & US Treasury \\
\hline
\end{tabular}

Source: IMF staff.

\section{This new dataset complements other existing data sources that are related to the} investor base. Except for the Merler and Pisani-Ferry (2012) data compilation on euro area countries, there is no publicly available cross-country database on government bond holdings. However, other sources are in part related to the dataset introduced in this paper. For instance, data on non-resident holdings largely coincide with external government debt as captured by the BIS-IMF-OECD-Worldbank Joint External Debt Hub (JEDH). A breakdown of non-resident holders into bank and non-bank investors could be derived from BIS consolidated banking statistics. The IMF's Global Financial Stability Report has laid out a comprehensive methodology for combining above sources to compile government bond holdings by residency. ${ }^{8}$ Other sources do not allow inferences on the composition of the investor base. For instance, financial account statistics record assets and liabilities by instrument, but not by holder.

\section{The underlying national data are likely to be revised in the context of efforts to} strengthen and standardize data collection and classification across countries. While there has been progress in closing data gaps related to financial exposures, existing data on government bond holdings should be used with care as data collection and processing methods are rapidly evolving. The Task Force on Finance Statistics has developed a global guide on public sector debt statistics that is hoped to set standards for data collection going forward. ${ }^{9}$ A key difficulty for data compilers consists in sourcing the primary data. Holding data are usually sourced from financial balance sheets, business surveys, and security

\footnotetext{
${ }^{8}$ See Annex 1.2, "Compilation of Investor Base Data for General Government Debt" in IMF (2011c).

${ }^{9}$ A draft "Public Sector Debt Statistics: Guide for Compilers and Users," has been made available in May 2011, http://www.tffs.org/PSDStoc.htm. See IMF (2011d).
} 
depositories. Recognizing the difficulty in reconciling these sources, different countries are in the process of setting up a centralized database for security holdings. One example is the ECB's Centralised Securities Database (CSDB). Yet, the heightened interest in government bond markets during this crisis demands a dataset that, even if less accurate, is immediately available. The data collection underlying this paper attempts to fill this void.

\title{
III. What ARE THE FACTS?
}

\begin{abstract}
A first look at the data reveals large differences with regard to the composition of countries' investor base for government securities. Figure 1 shows the composition of the investor base of government securities for 2011 or latest period available. Overall, it suggests that the investor base reflects region- or country-specific patterns. Canada, the United Kingdom, and the United States - countries with very deep financial markets and highly developed financial systems - exhibit a diversified investor base with significant holdings by all investor types. European countries (and Australia) show deep ties with non-resident investors. Further analysis would require a breakdown of non-resident investors by their respective sector and home country. In contrast, Japan and Korea have a very low share of non-resident holdings. Besides domestic financial institutions, government and state-owned enterprises are significant holders. ${ }^{10}$ These country differences are present over the entire sample period, notwithstanding common parallel changes in the composition of investors across regions.
\end{abstract}

In many countries, non-resident holders make up the largest share of the investor base. This is particularly the case for euro area countries, where the share of government securities held by investors outside the issuer country is among the highest in the sample. Aggregating the data for individual countries across the euro area (as shown in Figure 1), about one quarter of the outstanding debt is held by euro-area residents other than the issuing country, while another quarter is held by residents outside the euro area. Despite the apparently very high share of non-resident holdings in the euro area, on aggregate the euro area depends less on foreign buyers than the United Kingdom or the United States. The share of non-resident holdings has markedly increased during the last decade in all countries with the exception of Canada and Japan (Figure 2). After 2007, the trend has slowed, and even reversed in the case of some euro area countries (Greece, Ireland, Portugal, Spain).

\footnotetext{
${ }^{10}$ As data in this paper are presented on an unconsolidated basis where available, intragovernmental holdings are included, in contrast with the common practice. The difference is particularly noteworthy in the United States, where the Social Security Trust Fund holds about 20 percent of outstanding U.S. Treasuries. Intragovernmental holdings in Korea are likely to present only part of holdings by state-owned enterprises.
} 
Figure 1. Holders of government securities in $\mathbf{G 2 0}$ advanced countries and the euro area


Source: Country authorities, IMF staff calculations. 


\section{The existence of international financial centers could bias non-resident holdings}

upwards. Statistics on non-resident holdings often do not distinguish between intermediate holders and ultimate beneficiaries. For instance, the international financial service center in Ireland may record holdings where the ultimate beneficiary is a resident of the issuer country, thereby leading to an exaggeration of the ultimate risk held by foreigners. The Bank of Italy estimates that about 10 percent of non-resident holdings of Italian government securities can be attributed to Italian savers. ${ }^{11}$

\section{Figure 2. Non-resident holdings of government securities}

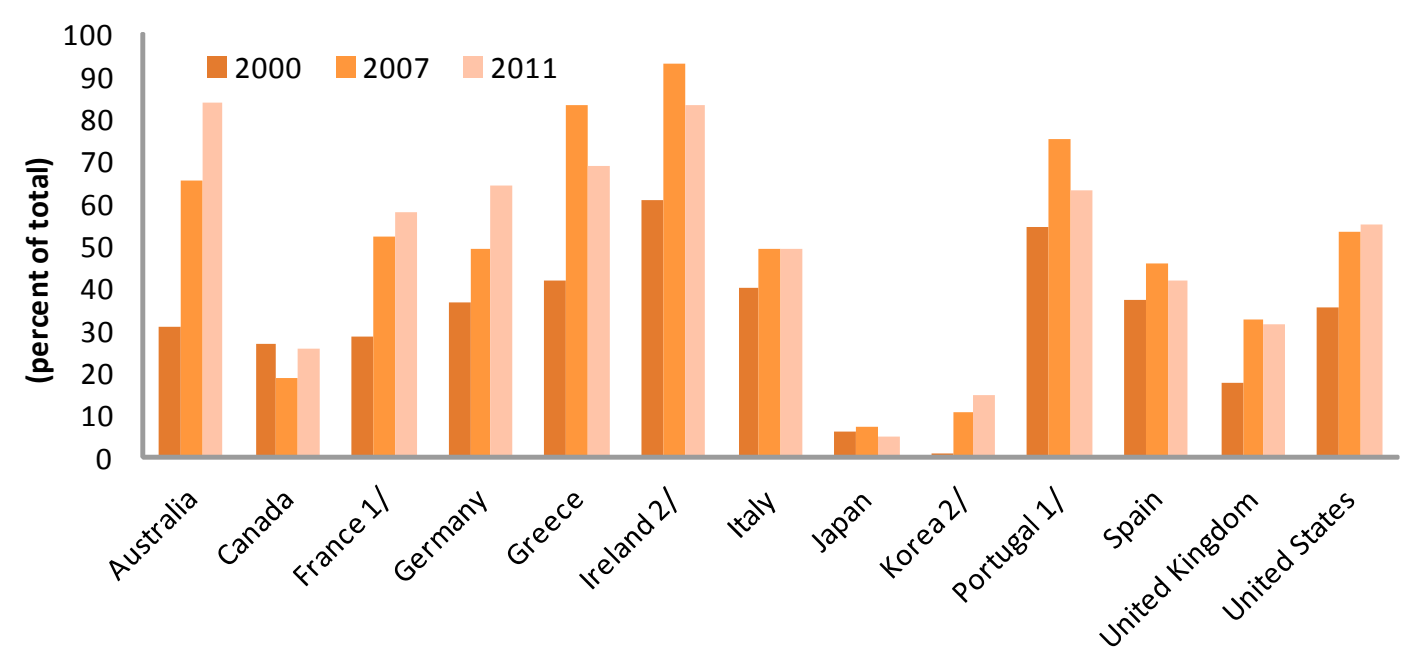

Sources: Country authorities, IMF staff calculations.

1/ Last observation refers to 2010. 2/ First observation refers to 2002.

\section{For reserve currencies, global imbalances and associated reserve flows of foreign} central banks or sovereign wealth funds were a factor behind the increase in nonresident holdings. Current account imbalances are mirrored by the accumulation of cross border financial claims which are often channeled into deficit countries' government bond markets (Table 2).$^{12} \mathrm{~A}$ simple regression associates a 1 percentage point increase in the current account deficit of reserve currency countries with an increase in non-resident holdings by 0.3 percentage points. Figure 3 provides a closer look at the United States for which very comprehensive data exist. More than two-thirds of the foreign-owned U.S. Treasury securities are classified as reserve holdings. Reserve accumulation has thus contributed most to the rise in non-resident holdings in U.S. Treasury securities until 2009, after which foreign official purchases slowed and their share in total non-resident holdings stagnated (see Figure 3, left panel). The U.S. Treasury (2011) points out that the acceleration

\footnotetext{
${ }^{11}$ See Banca D'Italia (2011), pp. 57f.

${ }^{12}$ Note that not all reserve assets may be invested in government bonds. Also, COFER data on the currency composition of international reserves cover only about half of total reserves. U.S. TIC data may also understate actual foreign reserve holdings (Bertraut et al., 2006).
} 
of foreign ownership of Treasury debt coincided with the devaluation of the Chinese Yuan in early 1994, a hypothesis supported by Treasury International Capital (TIC) data on the country composition of non-resident holdings (Figure 3, right panel).

Table 2. Reserve holdings (2010)

\begin{tabular}{|c|c|c|c|c|c|c|}
\hline & \multicolumn{4}{|c|}{ COFER database: Holdings by country group 1 / } & \multicolumn{2}{|c|}{ National sources 2/ } \\
\hline & Advanced & Emerging & Total & Total & & \\
\hline & \multicolumn{3}{|c|}{ (USȘ billion) } & $\begin{array}{l}\text { (percent of non- } \\
\text { resident holdings) }\end{array}$ & (USŞ billion) & $\begin{array}{l}\text { (percent of non- } \\
\text { resident holdings) }\end{array}$ \\
\hline Euro area & 665.2 & 682.7 & $1,347.9$ & 24.7 & $\ldots$ & $\ldots$ \\
\hline Japan & 127.0 & 68.0 & 195.0 & 43.5 & $\ldots$ & $\ldots$ \\
\hline United Kingdom & 68.9 & 133.8 & 202.7 & 43.0 & 95.7 & 20.3 \\
\hline United States & $1,736.0$ & $1,408.2$ & $3,144.3$ & 67.4 & $3,175.7$ & 68.0 \\
\hline
\end{tabular}

Sources: COFER, country authorities, IMF staff calculations.

$1 /$ Note that COFER data on the currency composition of international reserves cover only half of total reserves.

2/ Latest available (2011). Sources: UK Debt Management Office, TIC database.

Figure 3. Non-resident holdings of U.S. Treasury securities
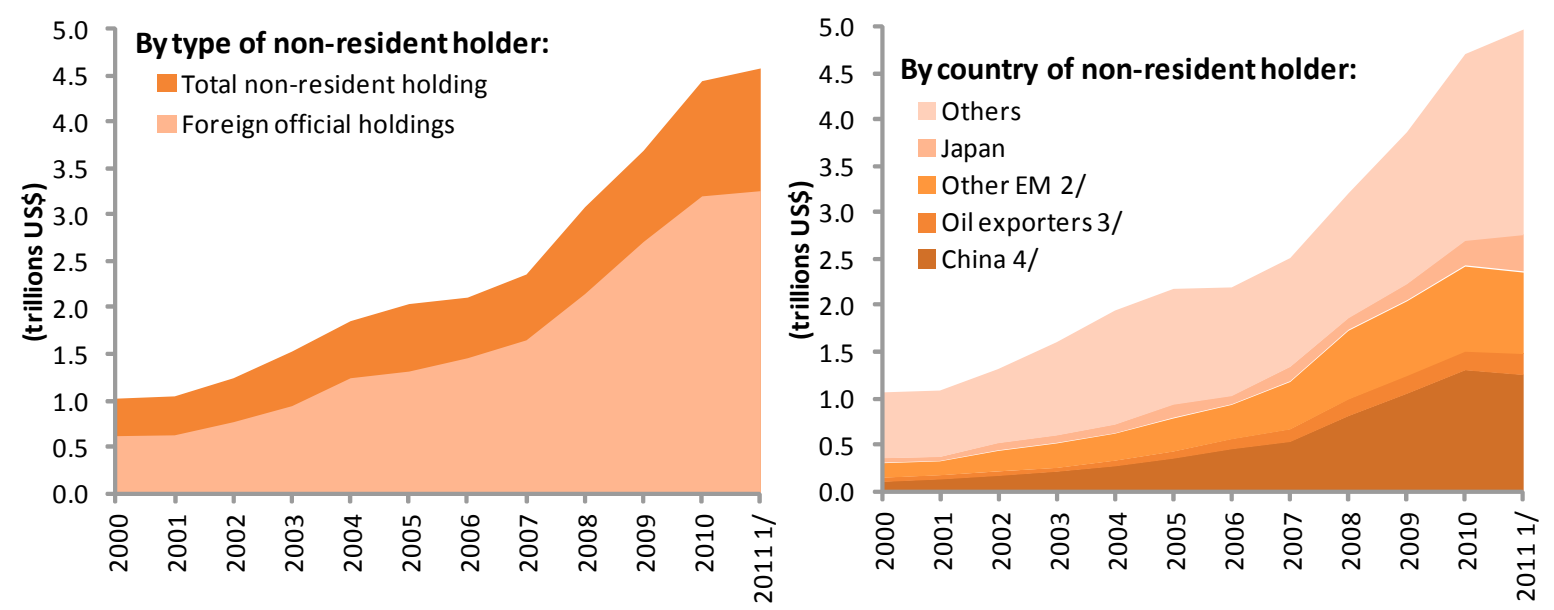

Source: U.S. Treasury TIC, IMF staff calculations.

$1 /$ August.

2/ Includes Brazil (from 2002), Caribbean banking centers, Chile (from 2008), Colombia (from 2008), India, Korea, Mexico, Russia (from 2007), Singapore, Taiwan, Thailand, and Turkey (from 2002).

3/Includes Ecuador, Venezuela, Indonesia, Bahrain, Iran, Iraq, Kuwait, Oman, Qatar, Saudi Arabia, the United Arab Emirates,

Algeria, Gabon, Libya, and Nigeria.

\section{The increase in non-resident holdings was also fueled by financial integration and}

regulatory changes. The period leading up to the global financial crisis was marked by a broad-based trend toward international financial integration, which in turn encouraged the international diversification of portfolios and larger cross-border holdings. This appears to be the main driver in many non-reserve countries. In addition, supporting regulatory changes catalyzed larger non-resident holdings. For example, government bonds of all euro area issuers received a zero risk weighting for the calculation of capital adequacy ratios. 
With the advent of the crisis, the trend towards larger non-resident holdings has stalled and, in some countries, started to reverse. Owing to the recent decline of current account imbalances (and changes to the management of international reserves), reserve accumulation has ceased to act as main driver of non-resident government bond holdings for reserve currency issuers. In other, riskier markets, the crisis triggered a marked pullback of foreign investors, repeating a typical pattern of increased home bias in the aftermath of crises. ${ }^{13}$ The recent tightening of prudential rules may have cemented this development.

Figure 4. Domestic portfolio share of government securities 1 /

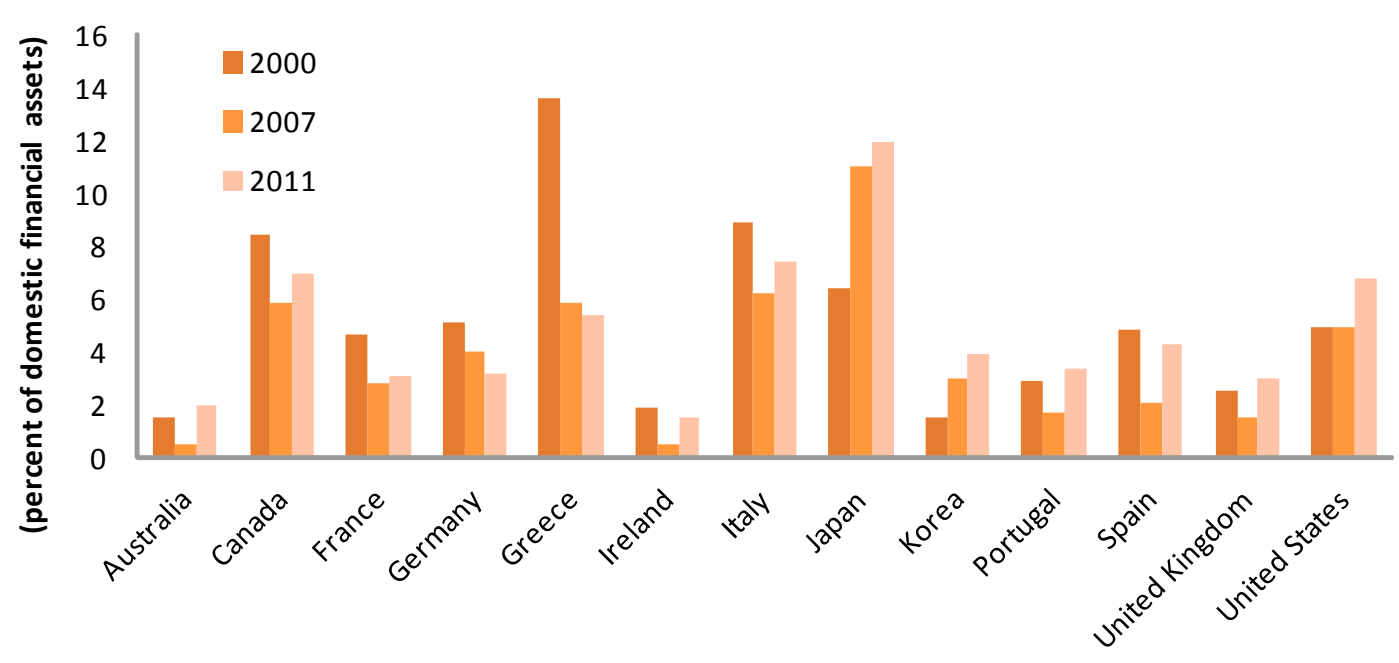

Sources: Country authorities, OECD.

1/ First observation refers to 2002 for Korea and 2001 for Ireland (estimated).

As flipside to the increasing share held by non-residents in the pre-crisis period, domestic investors held a lower share of government securities. With regard to the total outstanding, the share of government securities held in domestic accounts decreased prior to the crisis. Furthermore, the growth of other financial instruments dwarfed the issuance of government debt. As a result, the portion of domestically held government securities in percent of total domestic financial assets shrunk significantly in the run-up to the crisis (Figure 4). The decline was particularly pronounced in countries where financial systems deepened significantly or credit booms took place, such as Greece. These developments during the last decade did not apply to Japan. In Japan, high levels of new bond issuance were coupled with the deleveraging of balance sheets, causing the share of government securities in domestic portfolios to increase during the entire period. As the credit boom came to an end, the same development set in in other countries. Investors started to deleverage, while also seeking the safety of government bond investments (IMF 2011b). In

\footnotetext{
${ }^{13}$ See for instance Giannetti and Laeven (2012).
} 
many countries, the new supply of government securities caused by high deficits was over proportionally picked up by local investors.

\section{Among domestic holders, financial institutions are the most important investors in} government securities. Figure 5 shows government securities holdings as percent of total financial assets of financial institutions, derived from national accounts balance sheet data. Traditionally, bank holdings were low in market-based financial systems such as the United Kingdom and the United States. In the more bank-based financial systems of the euro area (and Canada), banks traditionally hold a larger share of their assets in government securities. (However, in countries where significant financial deepening took place, banks reduced their large holdings of government bonds.) Financial institutions hold a relatively high share in government securities in highly indebted countries, in particular Japan. ${ }^{14}$ In recent years, marked by the deleveraging and increased government deficits, financial sector holdings rose in many countries. The future outcome could possibly resemble the development in Japan over the last decade where increasing government debt and financial sector restructuring has lead to a sizable concentration of sovereign exposure in the financial sector. As a result, financial stability in Japan became closely intertwined with the stability of the government bond market.

Table 3. Public sector holdings (2011)

\begin{tabular}{|c|c|c|c|c|c|}
\hline & \multicolumn{5}{|c|}{ Holdings of the public sector in percent of total } \\
\hline & Government 1/ & Central bank & Social Security & $\begin{array}{c}\text { Public } \\
\text { corporations }\end{array}$ & Total \\
\hline Australia & 0.3 & 4.8 & $\ldots$ & $\ldots$ & 5.1 \\
\hline Canada & 13.0 & 5.1 & 1.7 & $\ldots$ & 19.8 \\
\hline France 2/ & $\ldots$ & 1.3 & $\ldots$ & $\ldots$ & $\ldots$ \\
\hline Germany & $\ldots$ & 0.3 & $\ldots$ & $\ldots$ & 0.3 \\
\hline Greece & 10.6 & $\ldots$ & $\ldots$ & $\ldots$ & 10.6 \\
\hline Ireland & 1.0 & $\ldots$ & $\ldots$ & $\ldots$ & 1.0 \\
\hline Italy & $\ldots$ & 5.2 & $\ldots$ & $\ldots$ & 5.2 \\
\hline Japan & 0.0 & 7.9 & 9.9 & 0.7 & 18.5 \\
\hline Korea & $\ldots$ & $\ldots$ & $\ldots$ & $\ldots$ & 23.9 \\
\hline Portugal 2/ & $\ldots$ & 0.8 & $\ldots$ & $\ldots$ & 0.8 \\
\hline Spain & 10.0 & $\ldots$ & $\ldots$ & $\ldots$ & 10.0 \\
\hline United Kingdom & 0.0 & 16.3 & $\ldots$ & 0.1 & 16.4 \\
\hline United States & 8.3 & 9.3 & 19.6 & $\ldots$ & 37.2 \\
\hline
\end{tabular}

Sources: Country authorities, IMF staff calculations.

1/ Central, state and local levels. 2/ Refers to 2010.

\footnotetext{
${ }^{14}$ In Italy, domestic banks hold a significant amount of other Italian government debt (6 percent of total assets) in addition to Italian government securities (7 percent of total assets).
} 
Figure 5. Share of domestic government security holdings in financial institutions
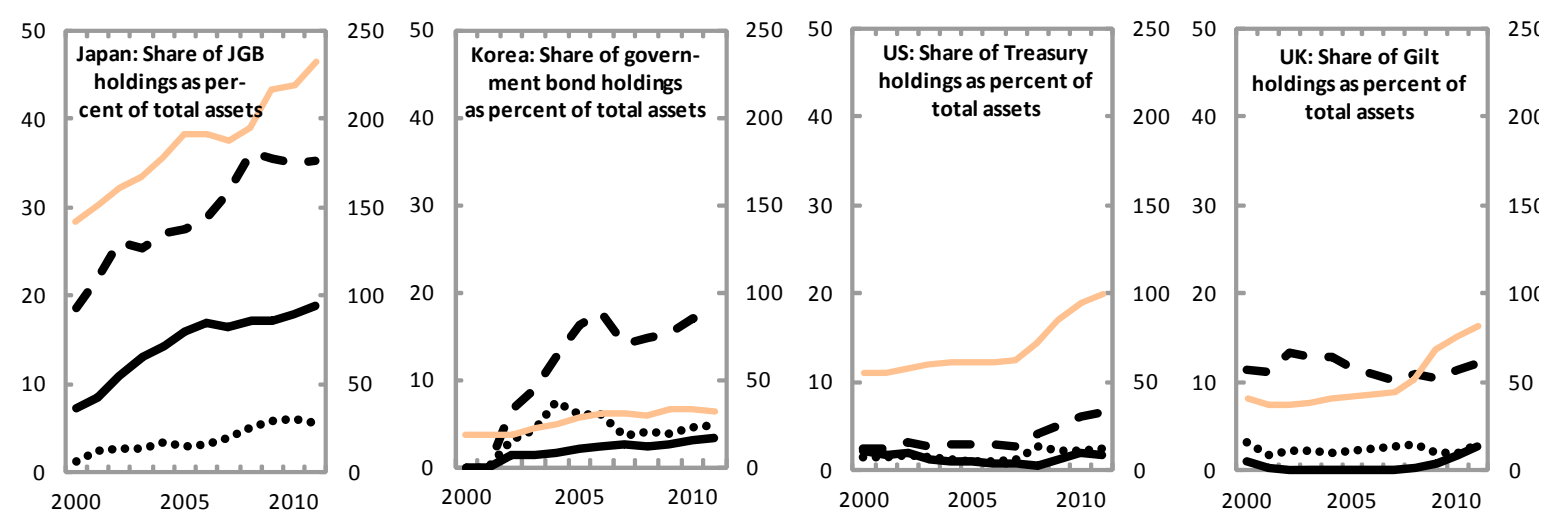

$\bullet \bullet \bullet$ Non-bank financial intermediaries

- Private insurance corp. and pension funds

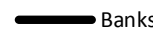

General government debt in percent of GDP (rhs)
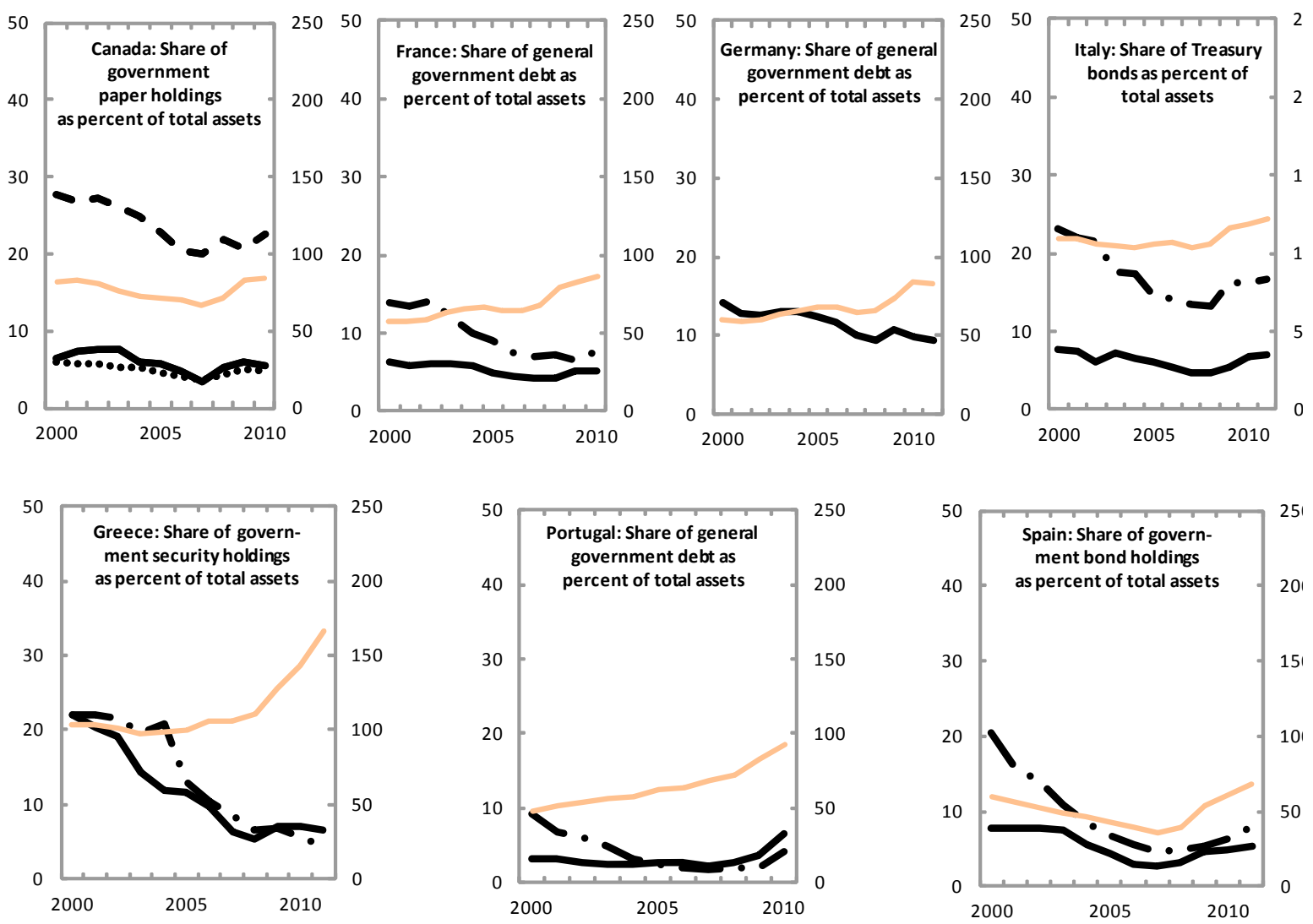

- Other financial institutions

Banks

- General government debt in percent of GDP (rhs)

Sources: Country authorities, ECB, OECD, IMF staff calculations.

Notes: The category "other financial institutions" is used for countries where a breakdown between non-bank financial intermediaries and private insurance and pension funds is unavailable. The central bank is included in "banks" for Spain, and in "other financial institutions" in Greece. No data other than for banks are available for Germany. Total unconsolidated assets are from annual OECD data. Latest data is for 2010 except for Germany and France (2009). 


\section{In some countries, public sector holdings of financial assets, and in particular} government securities, are large (Table 3). Holdings of government securities by the public sector are mostly related to central banks or social security funds. Central banks may maintain an active portfolio of government paper as part of their monetary operations, or hold government bonds from quantitative easing programs, among other smaller holdings. Social security services can operate within the central government (e.g., given the oversight of the ministry of health for health-related social security), or as a separate unit within the umbrella of the general government. While in the former set-up the social security administration does typically not hold a large investment portfolio, a separate fund may manage a sizable portfolio that includes government bonds. These holdings offset government liabilities in consolidated debt statistics. For instance, Table 3 shows large Treasury bond holdings of the U.S. Social Security Trust Fund which could be seen as mere accounting mechanism and cancel out in consolidated debt statistics for the U.S. general government. Also, an autonomous pension fund for public employees can form a separate institutional unit which is classified as public or private sector. ${ }^{15}$ In some cases, the statistical treatment has motivated the shift of pension fund savings from public corporations under the umbrella of the general government. ${ }^{16}$

\section{The comparative study of the composition of the investor base in advanced countries} has provided several insights. First, the run-up to the crisis was marked by increasing portions of securities held by non-resident investors. This trend was fuelled by reserve accumulation, financial integration, and a supportive regulatory environment. It has now ended and is unlikely to return in a comparable dimension. Second, domestic investors emerged as primary buyers of domestic issuance during the crisis while non-resident investors tended to withdraw. This pattern is reminiscent of previous crises, after which home bias increased. Third, large government securities holdings by financial institutions in Japan create a close link between risks in the bank and government bond market. This development could be indicative for other countries after the crisis where investors continue to deleverage and government debt expands. Fourth, public sector holdings of government securities are significant in many countries. While those holdings can be the result of central banks' large-scale asset purchases, there are often large holdings by public pension or social security funds. Institutional features determine their statistical treatment whereby holdings in institutions classified as general government are usually consolidated and therefore do not show up in statistics.

\footnotetext{
${ }^{15}$ See IMF (2011d), pp. 12ff, for the characteristics that determine the classification.

${ }^{16}$ For instance, in 1997 France assumed pension liabilities from France Telecom, which in turn transferred EUR5.7 billion to the government, accounted for as revenues. In 2010, Portugal undertook a similar transaction from Portugal Telecom for EUR2.6 billion. Other countries undertook related transactions.
} 


\section{DOES THE INVESTOR BASE MATTER?}

This section presents empirical evidence on the relationship between the investor base and government bond yields. Recently, high fiscal deficits resulted in a stepped-up supply of government securities while demand for financial investments underwent significant changes. In some cases, this has triggered notable shifts and heightened volatility of government bond yields. Demand for government bonds developed in a way that affected the investor base: Financial institutions were trying to reduce their balance sheets, and foreign buyers reduced their foreign exposure to all except the safest investments. Central banks initiated large-scale asset purchases, in part offsetting increased supply and the diminished demand by other buyers. Other domestic investors also sought the safety of domestic government bonds to invest excess liquidity or acquire premium collateral. An analysis of the econometric relationship between changes in the investor base and yields in a cross-country sample could be useful to insulate the implication of some of these developments from other, partly temporary issues that have affected bond markets recently.

\section{The goal is to test three prominent hypotheses regarding the connection between} investor base and bond yields. The first hypothesis is whether non-resident investment inflows have lifted government bond prices or have induced volatility. Domestic holdings are usually assumed to be more "sticky" than foreign investors'. Inflows of foreign portfolio debt investments have been identified as lifting asset prices in target markets, but those flows have traditionally been subject to sharp reversals (Levchenko and Mauro, 2006).${ }^{17}$ The second hypothesis investigated is whether a stable domestic investor base, including large pension and mutual funds, leads to lower yields and contains volatility. In contrast to non-resident investors, some domestic investors, such as insurance companies and pension and mutual funds, are associated with a more stable appetite for investments. These non-leveraged investors can better sustain temporary price volatility and are less prone to procyclical investment behavior compared with investors with shorter investment horizons and mark-tomarket reporting (IMF 2009). Finally, the third hypothesis researched is whether portfolio shifts, such as those arising from mandated or statutory purchases of government bonds, have a significant impact on expected returns in a mean-variance optimal portfolio framework. This puts the literature on central banks' large-scale asset purchases and foreign reserve accumulation in a broader context by extending the empirical analysis to portfolio composition shifts in general.

\section{A. Background}

\section{The literature on bond pricing provides an important backdrop for the empirical} investigation of demand effects. The reason is that the theoretical grounds for shifts in the investor base to cause changes in yields are narrow. Empirical results that associate changes in demand with changes in price should therefore be regarded circumspectly as to the direction of causality.

\footnotetext{
${ }^{17}$ A large body of literature exists for the closely related topic of sudden stops of capital flows to emerging markets. See, among others, Calvo (1998).
} 


\begin{abstract}
ing from credit and other risk premia, the theoretical literature identifies two fundamental pricing factors for bonds: (i) investor's substitution function of current against future consumption; and (ii) the universe of available instruments. While different investor groups may exhibit different substitution preferences, only a change in the aggregate preference or in the universe of available investible assets influence yields.
\end{abstract}

\title{
Market expectation theory suggests that yields depend only on investors' aggregate
} preference of future over current consumption. In frictionless markets, arbitrageurs level out differences in investor preferences for duration, resulting in flat demand curves of shortversus long-term bonds of otherwise similar characteristics. Shifts in demand preferences (such as from pension funds looking for longer duration bonds) or supply (such as issuers substituting shorter for longer tenure bonds) would not change the steepness of the yield curve. In empirical applications, the assumptions underlying this theory are often found to be violated. ${ }^{18}$ To the degree that changes in the investor base are associated with changes in intertemporal preferences, we would expect to see an impact on yields. An example is the introduction of pension regulations in the United Kingdom, inducing pension funds to hold assets of longer duration. Greenwood and Vayanos (2009) find that long-term yields declined significantly in the aftermath of these reforms.

\begin{abstract}
An analogous argument can be made with regard to risk preferences. If the universe of substitutable assets differs with regard to credit risk, spreads between assets of different credit risk should change in response to a change in the investor base that brings along a different risk preference. Non-resident investors often exhibit different risk preferences and view foreign risk as an uncorrelated diversification opportunity. ${ }^{19}$ Also, prudential regulation may raise banks' risk aversion, widening the yield between corporate and government bonds. ${ }^{20}$ Differences in risk preferences therefore motivate the first two hypotheses mentioned above about the influence of non-resident and domestic institutional investors on yields. It should be kept in mind, however, that investment-grade bonds are financial instruments where future income streams are known and carry minimal default risk. The effect of varying risk preferences will therefore translate only in fairly small yield differences.
\end{abstract}

\section{Apart from risk preferences, asset prices also depend on their correlation in a portfolio context. In portfolio theory, investor holdings are determined by risk-return preferences within a given universe of assets (Tobin, 1958). Demand and supply of savings need to balance, hence the theory postulates that the total return on all savings matches the aggregate}

\footnotetext{
${ }^{18}$ See, among others, Campbell and Shiller (1991).

${ }^{19}$ Diversification through foreign investments is the preposition of a large literature on international applications of portfolio models such as the CAPM. Transaction costs, differences in taxation and hedging, as well as asymmetric information are factors inhibiting full international diversification. See, among others, Burger and Warnock (2006) or Lane (2006).

${ }^{20}$ Also, Krishnamurthy and Vissing-Jorgensen (2008) show that a lower relative supply of Treasuries is associated with wider credit risk spreads.
} 
investor preference for risk. Given the risk-return profile of the aggregate market portfolio, each investor group would choose its individual portfolio composition according to its individual risk preference. Because idiosyncratic risks can be diversified, only an asset's systematic risk matters for the expected return demanded by investors in accordance with their risk preference. In a portfolio of traded securities, systematic risk is proxied by an asset's covariance with the aggregate investment portfolio (Markowitz, 1952). Given that government bonds usually have a positive correlation with the aggregate market portfolio, an increase in the supply of government bonds causes ceteris paribus its share in the market portfolio to increase, thus increasing its contribution to systematic risk and requiring an increase in returns. Additional demand, such as from the entry of a new investor, leads to lower yields. This approach has been used to estimate the impact of portfolio shifts from central banks' quantitative easing programs (Joyce et al., 2010; Neely, 2010) or foreign reserve management. Section IV.C uses the same approach.

Figure 6. Debt ratio and domestic financial sector portfolio holdings

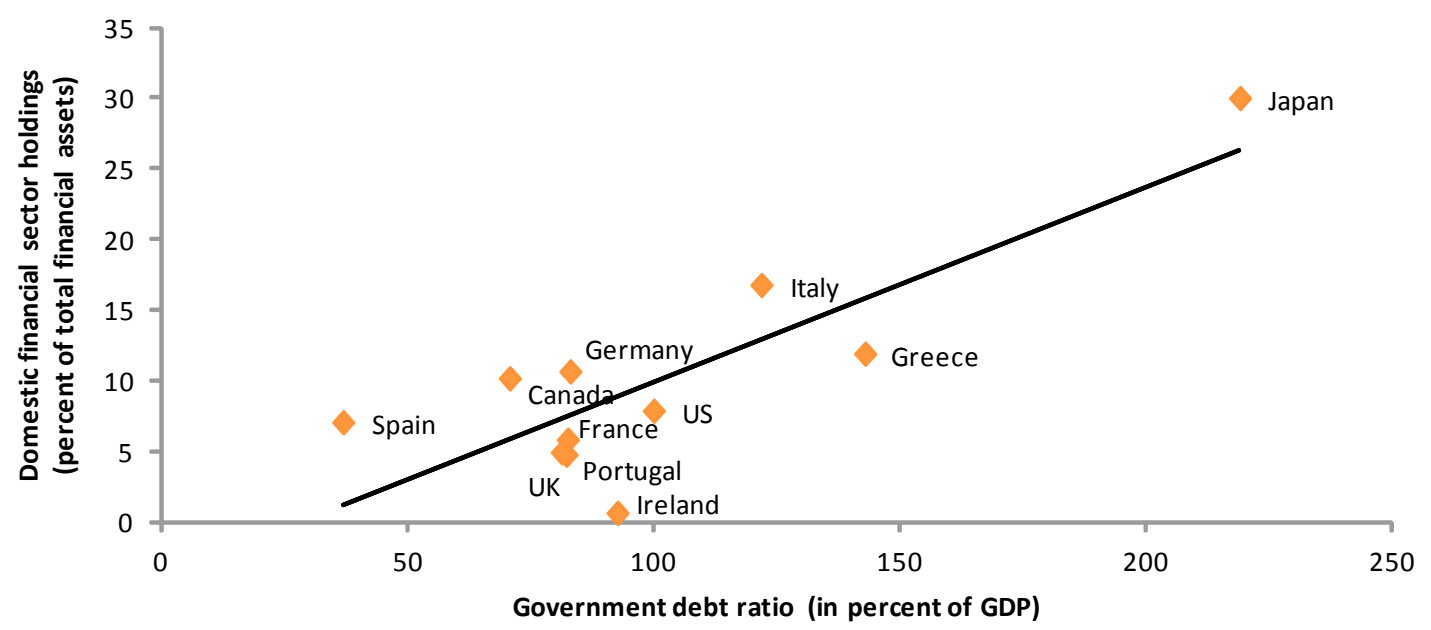

Source: Country authorities, OECD, IMF staff calculations.

Holding data refer to 2011 or latest available. Financial asset data refer to 2010 or latest available. The regression line has a slope of 0.13 and a R-squared measure of 69 percent. Excluding Japan results in a flatter regression line with slope coefficient of 0.07 .

This paper does not find merit in exploring the possibility of an empirical "saturation point" for government debt. Figure 6 plots outstanding government debt in percent of GDP against the share of government bond holdings on domestic financial sector balance sheets, suggesting a strong correlation. The correlation has motivated the argument that investors may reach a "saturation point" beyond which financial institutions are unwilling or unable to absorb more government debt on their balance sheet. Tokuoka (2010) and Hoshi and Ito (2011) extrapolate Japanese household savings and government deficits and calculate that gross public debt will exceed the stock of available financial assets in 10 to 15 years. However, the stock of domestic assets and thus the "absorption capacity" for more 
government debt are likely to be endogenous if higher government debts are balanced by higher savings. For that reason, the saturation argument is not further pursued here. ${ }^{21}$

\section{B. How Is the Investor Base Related to Yields?}

This section estimates regressions of bond yields with macro variables and holding data. Two different samples are used under different specifications (Table 4). The first sample contains an unbalanced quarterly time series of G20 advanced countries starting as far back as 1969. The second sample focuses on euro area countries and includes France, Germany, Greece, Ireland, Italy, Portugal, and Spain, starting in 2000. In both pooled regressions, the dependent variable is the quarter-end yield of 10 -year government bonds retrieved through Haver and Bloomberg. An additional regression of the volatility of bond yields uses the fourquarter rolling standard deviation as dependent variable. Data on the share of non-resident holdings is available for more countries and a longer time series, but information on holdings by other investors is available only for a shorter and less complete sample. To mitigate this shortcoming and use as many data points as possible, the G20 advanced and euro area samples are combined for regressions that include the share of public sector holdings and holdings of private non-bank financial institutions.$^{22}$ Control variables include the short-term interbank rate, real GDP growth, the government debt ratio and budget deficit, respectively. Other control variables, such as total debt outstanding, inflation, exchange rates, or the VIX (as proxy for risk aversion), were not found significant. This set of macro control variables yields results comparable to other studies, such as Baldacci and Kumar (2010). Given the non-stationarity of some variables, the reported results in this study are derived from regressions of quarterly changes of all variables.

\section{Regressions suggest a strong and robust association of lower yields with a larger share of non-resident holdings. Columns (1)-(7) in Table 4 show the resulting coefficients and} their t-statistics. Coefficients for macro controls, in particular the short rate, are significant but the sign of the real growth rate is ambiguous. The coefficient of the share of non-resident investors is consistently significant and negative. The result suggests that a 10 percentage point increase in the share of holdings by non-resident investors is associated with 32 to 43 basis points lower yields (up to 66 basis points for the euro area). The coefficient is smaller than previous empirical findings: With regard to foreign reserve accumulation in U.S. Treasury bonds, Warnock and Warnock (2006) and Beltran et al. (2012) find coefficients that would correspond to a reduction of 150 and 50 to 140 basis points, respectively. ${ }^{23}$ Beltran et

\footnotetext{
${ }^{21}$ Including the portfolio weight as proxy for the saturation does not result in a coefficient significantly different from zero in the regressions presented in the remainder of this paper. Yet, the possible endogeneity of investment savings motivate the complementary use of a VAR analysis in the following section.

${ }^{22}$ Public sector holdings include central banks. Private non-bank financial institutions refer to other financial intermediaries and financial auxiliaries, and insurance corporations and pension funds unless these institutions belong to the public sector, if data are available.

${ }^{23}$ For an overview of empirical studies, see also ECB (2006).
} 
al. (2012) also find that the coefficients for foreign private investors are similar to those of foreign official ones. Evidence from emerging market countries by Peiris (2010) attests that a 1 percentage point increase in the share of foreign investors results in a reduction of yields by about 6 basis points.

Yields are weakly and negatively associated with institutional investor holdings, but not with public sector holdings. Results for domestic private non-bank financial institutions and the public sector, reported in columns (4)-(7), are less clear cut. The share of non-bank private institutional investors shows a negative correlation with yields, suggesting that a 10 percentage point increase in their holding is associated with 26 basis points lower yields. This effect is not found in the euro area sample. Public sector holdings show an insignificant coefficient. As discussed in Section III, public sector holdings are not necessarily related to central banks' quantitative easing programs. Other empirical studies have found larger effects in direct response to central banks' large-scale asset purchases, ranging between 20 to 100 basis points in response to increases in central bank holdings between 2 to 4 (United States) and 15 percentage points (United Kingdom), respectively. ${ }^{24}$ Given that the remaining holding share is dominated by banks (as direct holdings of non-financial corporates and households are small), the results also suggest that bank holdings are associated with higher yields than holdings of the other investor groups.

\section{Higher non-resident holdings are associated with an increase in the volatility of yields.}

The significantly positive coefficient for non-resident holdings in column (8) suggests that a higher share of non-resident holdings is associated with a small but significant increase in the volatility of bond yields. The finding is in line with the large literature on volatility effects for other asset classes and for emerging markets with regard to foreign investors. ${ }^{25}$ The effect on bond yields may be larger when using specific crisis periods, analogous to the larger response to central bank large-scale asset purchases compared to public sector holdings in general. For instance, Borio and McCauley (1996) find strong and asymmetric effects during the bond market turbulence in Europe in 1994 when cumulative sales of non-resident investors reached between 1.8 (Italy) and 5.6 percent (France) of general government debt within a few months. Their estimates indicate an increase of the annualized volatility of daily yields between 2.1 and 5.3 percentage points in response to a change of 1 percent of nonresident holdings for their sample countries (Germany, France, and Italy).

\footnotetext{
${ }^{24}$ See, among others, Gagnon et al., 2010; D’Amico and King, 2010; Krishnamurthy and Vissing-Jorgensen, 2011; and Joyce et al., 2010. For a more complete discussion to contrast the results from these studies on central banks' large-scale asset purchases to other changes in bond holdership, see Beltran et al. (2012), pp. 14ff.

${ }^{25}$ See Bekaert and Harvey (2003), pp. 12ff.
} 


\begin{tabular}{|c|c|c|c|c|c|c|c|c|}
\hline \multirow[b]{3}{*}{ Number of countries } & \multicolumn{7}{|c|}{ 10-year benchmark yields } & \multirow{2}{*}{$\frac{\text { Yield StdDev }}{\text { G20 adv. }}$} \\
\hline & G20 adv. & $\begin{array}{l}\text { G20 adv. } \\
\text { excl. EA }\end{array}$ & Euro area & G20 adv. & $\begin{array}{l}\text { G20 adv. } \\
\text { excl. EA }\end{array}$ & Euro area & Combined & \\
\hline & 9 & 6 & 7 & 9 & 6 & 7 & 11 & 9 \\
\hline Period & $1969-2011$ & $1969-2011$ & $2000-2011$ & 1969-2011 & $1969-2011$ & $2000-2011$ & $2000-2011$ & $1969-2011$ \\
\hline [t-statistics in parentheses] & (1) & $(2)$ & (3) & (4) & (5) & (6) & (7) & (8) \\
\hline Constant & $\begin{array}{c}-0.0508 \\
{[-2.22]}\end{array}$ & $\begin{array}{l}-0.0531 \\
{[-1.85]}\end{array}$ & $\begin{array}{l}-0.0279 \\
{[-0.87]}\end{array}$ & $\begin{array}{l}-0.0705 \\
{[-3.12]}\end{array}$ & $\begin{array}{l}-0.0790 \\
{[-2.70]}\end{array}$ & $\begin{array}{l}-0.0610 \\
{[-1.59]}\end{array}$ & $\begin{array}{l}-0.0511 \\
{[-2.43]}\end{array}$ & $\begin{array}{l}-0.0232 \\
{[-2.22]}\end{array}$ \\
\hline Short-term interest rate & $\begin{array}{l}0.2231 \\
{[10.10]}\end{array}$ & $\begin{array}{l}0.2222 \\
{[9.03]}\end{array}$ & $\begin{array}{l}0.3444 \\
{[6.48]}\end{array}$ & $\begin{array}{l}0.1728 \\
{[6.18]}\end{array}$ & $\begin{array}{l}0.1722 \\
{[5.24]}\end{array}$ & $\begin{array}{l}0.2040 \\
{[3.36]}\end{array}$ & $\begin{array}{l}0.1588 \\
{[4.56]}\end{array}$ & \\
\hline Real GDP growth 1/ & $\begin{array}{l}0.0416 \\
{[2.25]}\end{array}$ & $\begin{array}{l}0.0465 \\
{[2.01]}\end{array}$ & $\begin{array}{l}-0.0249 \\
{[-1.37]}\end{array}$ & $\begin{array}{l}0.0546 \\
{[2.82]}\end{array}$ & $\begin{array}{l}0.0628 \\
{[2.51]}\end{array}$ & $\begin{array}{l}0.0287 \\
{[1.25]}\end{array}$ & $\begin{array}{l}0.0309 \\
{[1.95]}\end{array}$ & $\begin{array}{l}1.4278 \\
{[1.35]}\end{array}$ \\
\hline Budget balance $1 /$ & $\begin{array}{c}-0.0018 \\
{[-0.31]}\end{array}$ & $\begin{array}{l}-0.0007 \\
{[-0.11]}\end{array}$ & $\begin{array}{l}-0.0265 \\
{[-4.39]}\end{array}$ & $\begin{array}{c}-0.0031 \\
{[-0.56]}\end{array}$ & $\begin{array}{l}-0.0024 \\
{[-0.37]}\end{array}$ & $\begin{array}{l}-0.0240 \\
{[-2.91]}\end{array}$ & $\begin{array}{c}-0.0128 \\
{[-2.75]}\end{array}$ & $\begin{array}{l}0.0185 \\
{[2.42]}\end{array}$ \\
\hline Holding shares & & & & & & & & \\
\hline Non-resident investors & $\begin{array}{l}-0.0317 \\
{[-3.50]}\end{array}$ & $\begin{array}{c}-0.0338 \\
{[-3.24]}\end{array}$ & $\begin{array}{l}-0.0662 \\
{[-4.99]}\end{array}$ & $\begin{array}{l}-0.0325 \\
{[-3.59]}\end{array}$ & $\begin{array}{l}-0.0346 \\
{[-3.30]}\end{array}$ & $\begin{array}{c}-0.0559 \\
{[-3.04]}\end{array}$ & $\begin{array}{c}-0.0434 \\
{[-5.31]}\end{array}$ & $\begin{array}{l}0.0089 \\
{[2.42]}\end{array}$ \\
\hline Private non-bank financial institutions & & & & $\begin{array}{l}-0.0260 \\
{[-2.33]}\end{array}$ & $\begin{array}{l}-0.0254 \\
{[-1.97]}\end{array}$ & $\begin{array}{l}-0.0330 \\
{[-0.87]}\end{array}$ & $\begin{array}{l}-0.0256 \\
{[-1.99]}\end{array}$ & $\begin{array}{l}0.0057 \\
{[1.27]}\end{array}$ \\
\hline Public sector & & & & $\begin{array}{l}0.0006 \\
{[0.05]}\end{array}$ & $\begin{array}{l}-0.0003 \\
{[-0.02]}\end{array}$ & $\begin{array}{l}0.0588 \\
{[0.43]}\end{array}$ & $\begin{array}{l}-0.0088 \\
{[-0.69]}\end{array}$ & $\begin{array}{l}-0.0045 \\
{[-1.00]}\end{array}$ \\
\hline $\mathrm{N}$ & 644 & 470 & 269 & 565 & 391 & 194 & 439 & 565 \\
\hline R-squared & 0.18 & 0.19 & 0.22 & 0.12 & 0.12 & 0.16 & 0.13 & 0.03 \\
\hline
\end{tabular}

Sources: Country authorities, Bloomberg, Haver, IMF staff estimates.

1 / Absolute values used in regression (8).

\section{While these results establish an empirical relationship between yields and non-resident} and institutional investor holdings, the causality can go either way. The regressions show that falling yields are associated with an increase in the holding shares of non-residents or non-bank private institutional investors but do not establish a direction of causality. Nonresident holdings have often been seen as a driver of yields, in particular with regard to the dramatic convergence (and divergence) of yields in the euro area (see Figure 7). At the onset of the European currency union, short-term interest rates converged rapidly alongside longterm government bond yields. However, non-resident holdings increased during a longer period and stabilized or reversed only in 2008 for some countries. The relationship between non-resident holdings and yields may thus be more ambiguous than widely portrayed.

\section{The results of country-level causality tests suggest that the direction is very much} country- and investor-specific. Country-level granger causality tests provide separate test statistics on whether changes in the investor base precede yield changes ("push effect") or vice versa ("pull effect"). Results point to country- and investor-specific relationships. With regard to non-resident holdings, results point to pull effects in a consistent way in Australia, Canada, and Greece. France and Germany show evidence of push effects. ${ }^{26}$ For domestic

\footnotetext{
${ }^{26}$ The hypothesis that the yield changes do not induce changes in non-resident holdings (no pull effect) is rejected for Australia, Greece, Ireland, and Spain at a 5 percent confidence level and for Canada at a 10 percent confidence level. In turn, the hypothesis that changes in non-resident holdings do not induce yield changes (no push effect) is rejected for France, Germany, and Spain at a 5 percent confidence level and Ireland at a 10 percent confidence level.
} 
institutional investors, a pull effect is evident for France, Japan, Ireland, and Portugal, while a push effect appears at work in Italy. ${ }^{27}$

\section{Figure 7. Non-resident holdings and euro area yields}

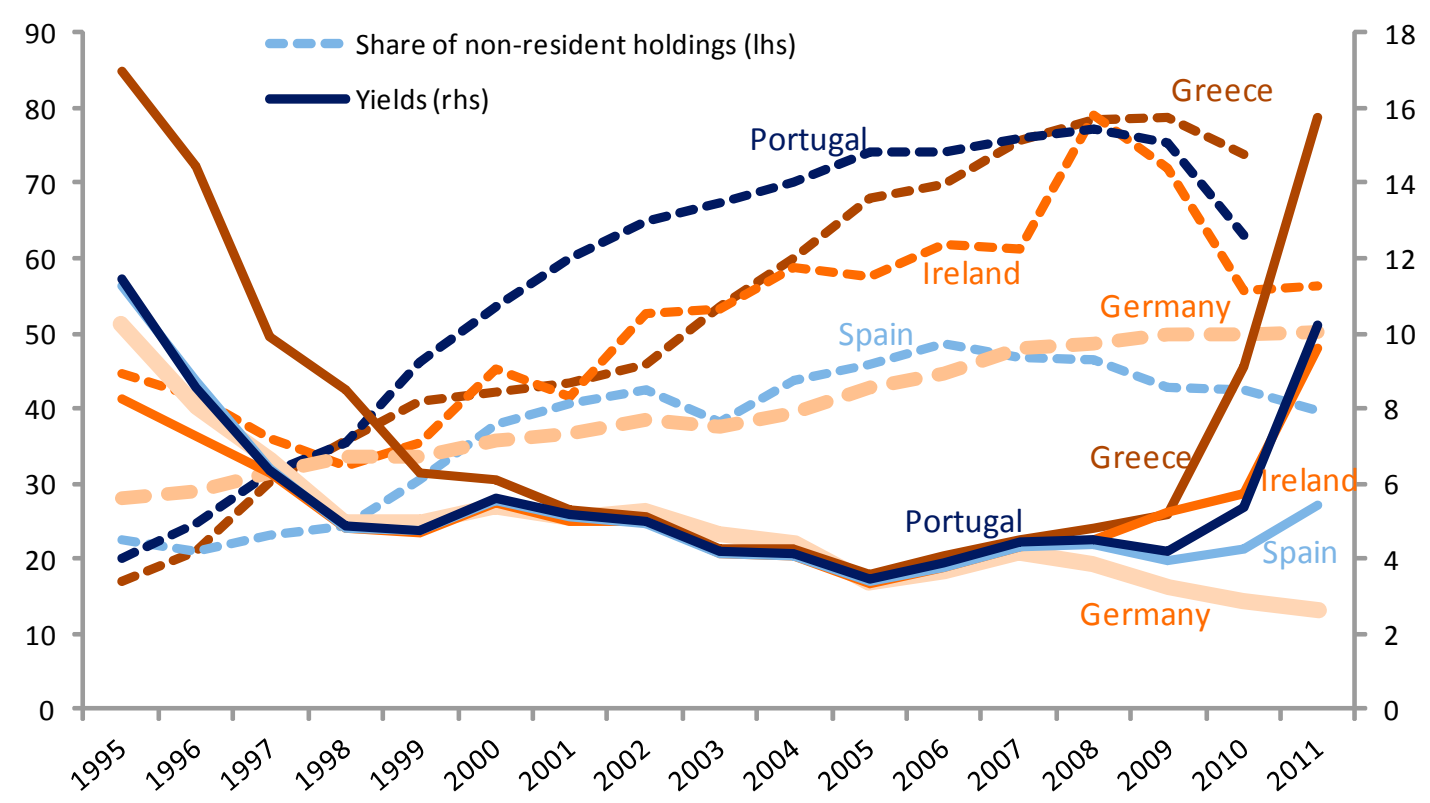

Sources: ECB, IFS, IMF staff calculations.

\section{A panel VAR suggests the existence of a pull effect in form of lower yields attracting} non-resident investors. A panel VAR of the sample countries including macroeconomic controls (assumed to be exogenous) is used to assess which directional effect dominates in the joint sample. ${ }^{28}$ While the coefficients for other investor groups remain insignificant, the results for non-resident holdings show an interesting pattern (Figure 8). In the full country sample, the significant short-term response can be interpreted as a pull effect (left panel), while there is no clear sign of a push effect (right panel). The results do not change noticeably when all euro area countries are excluded or when the period following the establishment of the euro area is cut off. For Greece, Ireland, Portugal and Spain, the impulse-response has a similar shape but a stronger coefficient for the pull effect.

Decomposing yields into a portion explained by macro controls and a residual shows that the pull effect is mostly associated with the unexplained part of yields. This could be interpreted as foreign investors entering foreign markets despite yields falling below levels warranted by fundamentals, and vice versa. The continuous increase in foreign holdings within the euro area-in view of an implicit guarantee and the "search for yield"- and strong foreign reserve

\footnotetext{
${ }^{27}$ The tests reject the null hypothesis that institutional sector holdings are not induced by yields (no pull effect) for Italy (at a 5 percent confidence level) and Germany (at a 10 percent confidence level). The hypothesis of no push effect is rejected for France, Germany, and Spain (at a 5 percent confidence level) and Ireland (at a 10 percent confidence level).
}

${ }^{28}$ The relative short time series prohibits the use of a crisis-subsample that could be compared to the pre-crisis period. 
accumulation during the pre-crisis period are consistent with the empirical results. An important caveat applies to these results as they are derived from a sample dominated by falling yields and increasing non-resident holdings. The recent reversal of this trend is still too short-lived to carry out a meaningful separate econometric analysis.

Figure 8. Impulse-response function
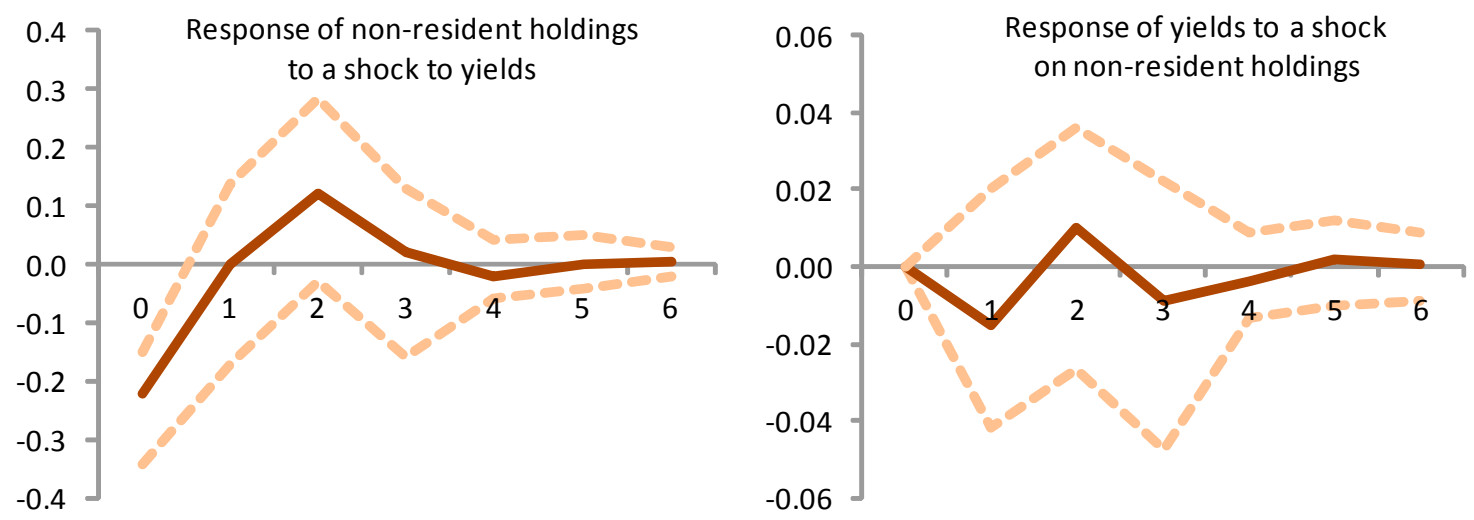

Source: IMF staff estimates.

Notes: PVAR with 3 lags. Shocks correspond to one standard deviation. 90 percent confidence band generated by Monte Carlo with 200 repetitions.

In summary, the regression results support the hypothesis that there is a significant relationship between non-resident holdings and the level and volatility of yields. Higher foreign participation is associated with higher asset prices throughout the regressions, a result that is consistent with other empirical studies. In contrast to the prevailing (albeit not uncontested) presumption, the evidence suggests that declines (increases) in yields are followed by inflows (outflows) of foreign investments in government securities. The impact of domestic institutional investors is somewhat weaker and fails to come out significantly in the VAR setting. No significant effect is found for public sector holdings. The regression also shows a significant yet small association between non-resident holdings and yield volatility.

\section{Do Portfolio Shifts Affect Expected Bond Returns?}

The portfolio balance approach allows estimating the change in expected returns following a shift in the relative weight of government bonds in investor's portfolios. According to the portfolio balance theory, investors' required return depends on the bonds' contribution to systematic risk. In a mean-variance portfolio optimization, agents choose portfolio weights $w$ in order to maximize a quadratic utility function representing a trade-off between expected portfolio return and its variance under a certain risk aversion parameter $\lambda$. The resulting portfolio weights are determined by

$$
w=\frac{1}{\lambda} \Sigma^{-1} r,
$$


where $r$ is the vector of expected excess returns from the available instruments and $\Sigma$ its covariance matrix (Roley, 1979). Assuming that $\Sigma$ is exogenous and homoscedastic, the change in returns from a change in portfolio weights $\Delta w$ can be calculated as

$$
\Delta r=\lambda \Sigma \Delta w
$$

The change in weights can be thought of as supply shock initiated either by changes to supply (such as an increase or decrease in the outstanding issuance of government bonds) or demand (such as investors purchasing bonds for purposes other than mean-variance optimization, effectively removing them from the pool of assets). This framework has been used to model the impact of central bank purchases for quantitative easing (Joyce et al., 2010; Neely, 2010) and foreign reserve holdings, assuming that these investors buy and hold the securities regardless of the mean-variance optimality for their portfolio. ${ }^{29}$ For the purpose of this paper, the shock can also be thought of as purchases of government bonds by banks, pension funds, and insurance companies motivated by changes in prudential rules, or purchases by foreign investors subject to a different efficiency frontier.

\section{The model is calibrated for Germany, Japan, the United Kingdom and the United}

States with data covering two decades. Financial asset holdings are derived from sectoral balance sheets in national accounts data, approximating the composition of market portfolios of government and corporate bonds, equities, deposits, and foreign portfolio investments. Expected excess returns and their covariance are proxied by monthly real returns starting in 1990 (where available). Foreign portfolios reflect the respective portfolio of all other countries in the respective domestic currency. Assuming no market frictions, the entire universe of financial assets is assumed to be allocated consistent with the mean-variance optimum.

\section{A 10 percent decrease in the mean-variance optimized holdings of government securities would cause expected bond returns to drop by 7 to 25 basis points (Table 5).} This shock can be interpreted as purchases equal to 10 percent of outstanding government securities for purposes other than portfolio optimization, resulting in a change in expected returns for those investors pursuing mean-variance optimal portfolios. The impact is linear to the shock. The 10 percent magnitude is within the range of portfolio reallocations in response to the Fed's or BoE's quantitative easing operations, or the estimated additional purchases of U.S. Treasury bonds following reforms of prudential norms. ${ }^{30}$ The resulting effect is lower than found in Neely (2010) whereby the Fed's US\$1.7 trillion quantitative easing initiative (equal to 22 percent of outstanding agency and Treasury debt) is estimated to have reduced expected returns by 88 basis points.

\footnotetext{
${ }^{29}$ As mentioned previously, this assumption looses appeal as reserve management is increasingly executed in the same way as private investment management. See Papaioannou et al. (2006) and Borio et al. (2008).

${ }^{30}$ The U.S. Treasury Office of Debt Management estimated in 2011 that regulatory reforms could add US\$675 billion of demand for treasury bonds owing to Basel III liquidity regulation for banks, and US\$425 billion owing to Dodd-Frank and FASB reforms for pension and insurance funds. This total corresponds to 7 percent of outstanding treasury bonds and 0.8 percent of the total market portfolio in 2011. See U.S. Treasury (2011).
} 
Table 5. Change in expected real return after 10-percent supply shock

\begin{tabular}{|c|c|c|c|c|c|}
\hline \multirow{3}{*}{ (in percent) } & \multirow{3}{*}{$\begin{array}{c}\text { Portfolio } \\
\text { shift }\end{array}$} & \multicolumn{4}{|c|}{ Change in return on } \\
\hline & & \multicolumn{2}{|c|}{ Bonds } & \multirow[t]{2}{*}{ Equities } & \multirow{2}{*}{$\begin{array}{c}\text { Foreign } \\
\text { portfolic }\end{array}$} \\
\hline & & Government & Corporate & & \\
\hline Germany & 0.7 & -0.08 & -0.03 & 0.29 & 0.02 \\
\hline Japan & 1.9 & -0.25 & -0.10 & 1.64 & 0.28 \\
\hline United Kingdom & 0.3 & -0.07 & -0.01 & 0.02 & 0.03 \\
\hline United States & 0.9 & -0.16 & -0.07 & 0.37 & 0.01 \\
\hline
\end{tabular}

Sources: Bloomberg, OECD, IMF staff calculations.

The portfolio approach may underestimate the impact on yields. First, the asset class of government securities in this sample has a fairly high correlation with the market portfolio, resulting in betas of between 0.7 (Germany) and 1.1 (United Kingdom). Also, basing the calculation on historic returns and variance may have little predictive power given that government bonds of the sample countries generated exceptional excess returns during the last two decades. Second, if the shock is also thought of as affecting other parts of the portfolio, such as from bank deleveraging or government issuance crowding out private borrowing and reducing the size of the portfolio, the effect would be larger. Finally, the effect shown here also rests on the expectation that the change in the outstanding bonds is permanent, which may not be the case even for large quantitative easing programs which in part offset higher supply from cyclical fiscal deficits.

\section{Conclusions}

A new dataset on sectoral holdings of government securities shows sizable differences in the investor base between countries. The database introduced in this paper contains data on government securities for the advanced G20 countries and the euro area during 2000-2010, with data for a few categories reaching further back. The largest investor groups are found to be non-residents, banks and other institutional investors, as well as the public sector. Except for Japan where the investor base is predominantly domestic, non-residents increased their holdings in the period prior to the crisis. Besides financial integration, in particular among euro area countries, current account imbalances and corresponding reserve accumulation are likely the main drivers of larger cross border holdings. During the crisis, the share of securities held by non-residents has been stagnant or falling in most countries while government debt expanded. Domestic government bond holdings mirror this trend, and domestic institutions have often picked up the incremental supply in government debt. The increased holdings of the financial sector mark the end of a prolonged period during which government securities made up a small and shrinking share of investors' balance sheets. An exception to this observation is Japan, where ongoing deleveraging and large public deficits continually increased the portfolio weight of government securities during the last decade. In some countries there are also large public sector holdings which, depending on the classification of the holding unit, may be consolidated into the general government and thus escape most debt statistics. 
Econometric evidence suggests a link between the investor base and bond yields. Regressions show a significant negative correlation between changes in the bond yield and the share of securities held by non-residents and domestic institutional investors. An increase in the share of securities held by non-residents by 10 percentage points is associated with a decline in yields of 32 to 43 basis points, and up to 66 basis points in the euro area. For domestic institutional investors, the effect is somewhat smaller at about 26 basis points and less robust. The data thus lend support to the notion that larger non-resident and also institutional investor holdings are associated with lower yields. There is also some evidence that the volatility of yields is associated with the share of non-resident holdings, which are perceived to be less "sticky".

\section{Granger causality tests and a panel vector autoregression point to lower yields} attracting non-resident investors. The causality between changes in holding shares and yields could go either way. Increases in holding shares, mostly related to investment flows into government securities, could be interpreted as "push effect" of increasing (decreasing) demand for government securities leading to lower (higher) yields. The reverse causality could be interpreted as a "pull effect" whereby a change in yields, such as from changes to macroeconomic fundamentals, induces a change in the investor base. For non-resident investment flows there appears to be a pull effect that dominates in the full sample, and particularly for the euro area periphery. The result becomes more pronounced when using a two-stage regression in which residuals unexplained by macroeconomic controls are deployed in a panel VAR. These results suggest that non-resident holdings seem to follow on the heels of changes in yields, partly beyond what can be explained through credit fundamentals.

\section{A compositional shift of 10 percent of government bonds out of mean-variance optimized portfolios into statutory or regulatory holdings would lower expected returns by up to 25 basis points. A portfolio balance approach is used to analyze the effect of a reduction in the free float of government bonds by 10 percent of the outstanding stock in Germany, Japan, the United Kingdom, and the United States. Such shock could arise from asset purchase programs by central banks or increases in regulatory holdings by banks and investment funds. These purchases would reduce the weight of government securities in other investors' portfolios, resulting in a reduction of expected returns. The calculated changes in expected returns range between 7 and 25 basis points. This result is at the lower end of previous estimates, possibly given that the underlying data originate from a decade- long bull market for government bonds.}

Future research will add further insight on the questions discussed in this paper. The paper at hand is part of the nascent literature linking balance sheets to financial flows, providing a starting point for future research. To the knowledge of the author, this dataset is the first of its kind to provide cross-country data on holdings of a certain asset class. Further expansion and completion of the data could be used to put more sophisticated econometric approaches, such as the one by Beltran et al. (2012), to the test in a multi-country setting. Also, complementing these data with sectoral balance sheets and from-whom-to-whom accounts will allow the exploration of the links between financial exposures, transactions, and price changes. 


\section{References}

Baldacci, E., and M. Kumar, 2010, "Fiscal Deficits, Public Debt, and Sovereign Bond Yields," IMF Working Paper 10/184.

Banca D'Italia, 2011, “Financial Stability Report,” No. 2, November 2011.

Bekaert, G., and C. Harvey, 2003, “Emerging Markets Finance,” Journal of Empirical Finance, Vol. 10

Beltran, D., M. Kretchmer, J. Marquez, and C. Thomas, 2012, "Foreign Holdings of U.S. Treasuries and U.S. Treasury Yields," Federal Reserve Board, Washington D.C.

Bertraut, C., W. Griever, and R. Tyron, 2006, "Understanding U.S. Cross-Border Securities Data," Federal Reserve Board, Washington D.C.

Borio, C., G. Galati, and A. Heath, 2008, "FX Reserve Management: Trends and Challenges," BIS Papers No. 40.

Borio, C., and R. McCauley, 1996, "The Economics of Recent Bond Yield Volatility,” BIS Economic Papers No. 45.

Burger, J., and F. Warnock, 2006, "Foreign Participation in Local Currency Bond Markets," NBER Working Paper 12548, Cambridge, Mass.: National Bureau of Economic Research.

Calvo, G., 1998, "Capital Flows and Capital-Market Crises: The Simple Economics of Sudden Stops,” Journal of Applied Economics, Vol. 1 (1).

Campbell, J., and R. Shiller, 1991, "Yield Spreads and Interest Rates: A Bird's Eye View," Review of Economic Studies, Vol. 58.

D’Amico, S., and T. King, 2010, "Flow and Stock Effects of Large-Scale Treasury Purchases," Federal Reserve Board, Washington, D.C.

De Santis, R., and B. Gerard, 2006, "Financial Integration, International Portfolio Choice, and the European Monetary Union," ECB Working Paper 626.

European Central Bank (ECB), 2006, "The Accumulation of Foreign Reserves," ECB Occasional Paper Series No. 43.

Fidora, M., M. Fratzscher, and Christian Thimann, 2006, "Home Bias in Global Bond and Equity Markets," ECB Working Paper 685.

Gagnon, J., M. Raskin, J. Remache, and B. Sack, 2010, "Large-Scale Asset Purchases by the Federal Reserve: Did They Work?” FRBNY Staff Report No. 441. 
Giannetti, M., and L. Laeven, 2012, "The Flight Home Effect: Evidence from the Syndicated Loan Market during Financial Crises," Journal of Financial Economics, Vol. 104 (1).

Greenwood, R., and D. Vayanos, 2009, "Price Pressure in the Government Bond Market," Unpublished.

Hoshi, T., and T. Ito, 2011, "Defying Gravity: How Long Will Japanese Government Bond Prices Remain High?” Presentation at the IMF Research Department, September 2011.

International Monetary Fund, 2009, "Policies to Mitigate Procyclicality," Staff Position Note 09/09.

,2011a, "Fiscal Monitor (September 2011)."

,2011b, "Global Financial Stability Report (September 2011).”

,2011c, “Global Financial Stability Report (April 2011).”

, 2011d, "Public Sector Debt Statistics: Guide for Compilers and Users."

, 2012, "Global Financial Stability Report (April 2012).”

Joyce, M., A. Lasaosa, I. Stevens, and M. Tong, 2010, “The Financial Market Impact of Quantitative Easing in the United Kingdom,” Bank of England Working Paper 393.

Krishnamurthy, A., and A. Vissing-Jorgensen, 2010, "The Aggregate Demand for Treasury Debt," NBER Working Paper 12881, Cambridge, Mass.: National Bureau of Economic Research.

,2011, “The Effects of Quantitative Easing on Interest Rates," Northwestern University, Unpublished.

Lane, P., 2006, “Global Bond Portfolios and EMU,” ECB Working Paper 553.

Levchenko, A., and P. Mauro, 2006, "Do Some Forms of Financial Flows Help Protect from Sudden Stops?” IMF Working Paper 06/202.

Markowitz, H.M., 1952, "Portfolio Selection," Journal of Finance, Vol. 7 (1).

Merler, S., and J. Pisani-Ferry, 2012, “Who’s Afraid of Sovereign Bonds?” Bruegel Policy Contribution Issue 2012/02.

Neely, C., 2010, "The Large-Scale Asset Purchases Had Large International Effects," Working Paper, Federal Reserve Bank of St. Louis. 
Papaioannou, E., R. Portes, and G. Siourounis, 2006, "Optimal Currency Shares in International Reserves: The Impact of The Euro and The Prospects for The Dollar," Journal of the Japanese and International Economies, Vol. 20 (4).

Peters, M., 2002, "Estimating Default Probabilities of Emerging Market Sovereigns: A New Look at the Not-So-New Literature," HEI Working Paper 06/2002.

Peiris, S., 2010, “Foreign Participation in Emerging Markets' Local Currency Bond Markets,” IMF Working Paper 10/88.

Reinhart, C., and S. Sbrancia, 2011, ”The Liquidation of Government Debt,“ NBER Working Paper 16893, Cambridge, Mass.: National Bureau of Economic Research.

Roley, V., 1979, “A Theory of Federal Debt Management.” American Economic Review, Vol. 69 (5).

Tobin, J., 1958, "Liquidity Preference as Behavior Towards Risk," Review of Economic Studies, Vol. 25.

Tokuoka, K., 2010, “The Outlook for Financing Japan's Public Debt,” IMF Working Paper $10 / 19$.

U.S. Treasury Office of Debt Management, 2011, "Presentation to the Treasury Borrowing Advisory Committee,” Unpublished, February 2011.

Warnock, F., and V. Warnock, 2006, "International Capital Flows and U.S. Interest Rates," NBER Working Paper 12560, Cambridge, Mass.: National Bureau of Economic Research. 